\title{
Bacterial Isolates from Seafood in Scotland
}

\author{
Ngozi Izuchukwu \\ Institute of Aquaculture, School of Natural Sciences, University of Stirling, Stirling, FK9 4LA, UK
}

\begin{abstract}
Vibrio spp., Enterobacteriaceae representatives and Listeria monocytogenes were isolated from commercially prepared smoked and fresh Atlantic salmon, smoked and fresh haddock, live mussels and oysters. Isolates were identified phenotypically and by sequencing the $16 S$ rDNA gene. Vibrio spp. occurred in high densities ( $>10^{6} \mathrm{CFU} \mathrm{g}^{-1}$ ) in mussels. Enterobacteriaceae representatives were recorded at $2.2 \times 10^{6} \mathrm{CFU} \mathrm{g}^{-1}$ and $2.0 \times 10^{6} \mathrm{CFU} \mathrm{g}^{-1}$ in fresh salmon and smoked haddock, respectively. Total heterotrophic counts in fresh salmon, live mussels and oysters reached $10^{7}, 10^{7}$ and $10^{6} \mathrm{CFU} \mathrm{g}^{-1}$, respectively. Listeria monocytogenes was recorded at $5.0 \times 10^{4} \mathrm{CFU} \mathrm{g}^{-1}$ in mussels. The prominent characteristics of fish spoilage isolates were demonstrated by the ability of the isolates to reduce trimethylamine oxide (TMAO) to trimethylamine, and to produce $\mathrm{H}_{2} \mathrm{~S}$. The spoilage organisms revealed the ability to produce hydrolytic enzymes.
\end{abstract}

Keywords: Enterobacteriaceae, filter feeders, fish fillets, fish spoilage bacteria, Listeria monocytogenes, Vibrio spp.

\section{Introduction}

Fishery products are significant for human nutrition worldwide [1], but may also serve as a source of foodborne pathogens [2]. Chemicals, metals, marine toxins, and infectious agents, i.e. bacteria, viruses, and parasites, have been detected in seafood, and may be associated with mild gastroenteritis to life-threatening diseases [3]. Microbial contamination of fish tissues may reflect the presence of pollutants in the aquatic environment [4]. This contamination by pathogens poses a potential risk to human health [5]. Specifically, the consumption of raw or undercooked seafood is especially problematic to human health. Filter feeders, such as mussels, and oysters, are particularly troublesome in terms of microbial contamination insofar as the animals collect bacteria in their filtering systems. Thus, they entrap pathogenic and non-pathogenic bacteria and viruses that occur in the aquatic environment [6].

The presence of putative pathogens, such as Vibrio parahaemolyticus, Listeria monocytogenes, Staphylococcus aureus, Clostridium perfringens and Edwardsiella tarda, have been documented in conger eel, swordfish, sole, grouper, and whiting [2]. This study attempts has focused on potential pathogenic and spoilage microorganisms isolated from seafood in Central Scotland.

\section{Sample collection}

\section{Materials And Methods}

The seafood samples were obtained from Edinburgh and Stirling, Scotland, UK from March to April, 2010. Thus, fresh salmon and haddock fillets, chosen from within the middle of stacks of fillets in chilled display cabinets within fishmongers, were collected by use of disposable plastic gloves and packed in sealed aluminium foil packs. Enquiries of the fishmongers confirmed that in all cases the fish had been landed from fishing boats within the previous $24 \mathrm{~h}$, although it was unknown how long the fish had been on the boats after capture. Filleting of the whole fish occurred in the shops within the same day as purchase, and the fillets were immediately displayed in refrigerated cabinets. Smoked haddock fillets were obtained by the fishmongers from a commercial smoke house in Leith, Edinburgh. The smoked salmon was pre-packed, and was sourced from farmed Atlantic salmon that had been smoked in the Highlands of Scotland. There was a lack of clarity about the origin of bags of live mussels and oysters, which were obtained by the fishmongers from wholesalers. All animals were sourced from Scotland. There was not any stated shelf life for any of the fresh fish or shellfish purchases.

Samples from fishmongers in Stirling were packed in polyethylene wraps, and stated to be fresh with a $24 \mathrm{~h}$ use-by date. The samples from Edinburgh were transported to the laboratory within one hour of collection, and were maintained in a cold box at $4^{\circ} \mathrm{C}$. The samples from Stirling were transported at room temperature, and were processed microbiologically within 20 min of collection. In total, 4 samples of cold smoked salmon, 4 samples of fresh salmon, 4 bags of mussels, one sample of cold smoked haddock, one sample of fresh haddock, and one bag of oysters were examined.

\section{Microbiological Examination}

The samples were analysed for the presence of Vibrio spp., Enterobacteriaceae representatives on eosin methylene blue agar, total aerobic heterotrophic counts, and Listeria monocytogenes after $[7 ; 8 ; 9 ; 10]$, 
respectively. The microbiological procedures involved blending [using Stomacher Lab-Blender-80] $10 \mathrm{~g}$ quantities of each seafood sample in $90 \mathrm{ml}$ of [30\% (w/v) alkaline peptone water for vibrio, $0.5 \%(\mathrm{w} / \mathrm{v})$ peptone water for Enterobacteriaceae and sterile $0.85 \%$ (w/v) saline for total heterotrophic counts broth for $2 \mathrm{~min}$. The recovery of Listeria spp. involved pre-enrichment on Listeria primary selective enrichment broth base (Oxoid, CM0863) supplemented with Listeria primary selective enrichment supplement (Oxoid, SR0142E) (UVM I) following incubation at $30{ }^{\circ} \mathrm{C}$ for $24 \mathrm{~h}$ and Listeria secondary selective enrichment broth base CM0863 supplemented with Listeria secondary selective enrichment supplement (Oxoid, SR0143E) (UVM II) followed by cultures on PALCAM agar following incubation at $30{ }^{\circ} \mathrm{C}$ for $48 \mathrm{~h}$ as recommended by [10].The number of colonies was recorded before a random assortment was picked, and purified by streaking and restreaking on tryptone soya agar (TSA; Oxoid) plates supplemented with $1 \%(\mathrm{w} / \mathrm{v})$ sodium chloride [= TNA] with incubation at $30^{\circ} \mathrm{C}$ for $48 \mathrm{~h}$ [11].Carnobacterium maltaromaticum isolates [from smoked salmon] were grown routinely on de Man Rogosa and Sharpe agar (MRS; Oxoid) at $30{ }^{\circ} \mathrm{C}$ for $48 \mathrm{~h}$. Stock cultures were stored in tryptone soya broth (TSB; Oxoid) supplemented with $1 \%(\mathrm{w} / \mathrm{v})$ sodium chloride [= TNB] and $20 \%(\mathrm{v} / \mathrm{v})$ glycerol at $-70{ }^{\circ} \mathrm{C}[12]$.

\section{Identification Of The Bacteria}

All cultures were examined for micromorphology using Gram-stained smears, motility, colonial morphology, catalase and oxidase production, and the oxidative-fermentative metabolism of glucose using standard procedures by [13], before recourse to use of the API 20E, API 50CH ((BioMerieux ${ }^{\circledR}$ Marcy-l'Etoile, France) and MICROBACT ${ }^{\mathrm{TM}}$ Listeria 12L (Thermoscientific) rapid identification systems. Isolates were identified by $16 \mathrm{~S}$ rDNA amplification, sequencing and species attribution [14].

\section{Bio-Activity Of The Cultures}

Cultures were examined for DNase, Trimethylamine oxide (TMAO) reduction and $\mathrm{H}_{2} \mathrm{~S}$ production, lecithinase and lipase, gelatinase, esterase and coagulase activities after $[15 ; 16 ; 17 ; 18 ; 19 ; 13]$, respectively. Haemolytic activity to $5 \%(\mathrm{v} / \mathrm{v})$ defribrinated sheep blood in blood agar base (Oxoid) supplemented with $1 \%$ $(w / v)$ sodium chloride was recorded after incubation at room temperature for 4 days.

Isolation of microorganisms from seafood:

\section{Results}

The mean presumptive numbers of Vibrio, Enterobacteriaceae, aerobic heterotrophs, and L. monocytogenes were from $2.8 \times 10^{3}$ to $2.1 \times 10^{6} \mathrm{CFU} \mathrm{g}^{-1}, 5.0 \times 10^{2}$ to $2.2 \times 10^{6} \mathrm{CFU} \mathrm{g}^{-1}, 1.6 \times 10^{3}$ to $5.8 \times 10^{7} \mathrm{CFU} \mathrm{g}^{-1}$ and $1.0 \times 10^{4}$ to $5.0 \times 10^{4} \mathrm{CFU} \mathrm{g}^{-1}$, respectively (Tables $1,2,3$ and 4 ).

Table 1. Presumptive Vibrio counts of the seafood samples

\begin{tabular}{|c|c|c|c|}
\hline Date of seafood collection & seafood samples & $\begin{array}{l}\text { Colony count } \mathrm{CFU} \mathrm{g}^{-1} \text { on } \\
\text { TCBS at } 30^{\circ} \mathrm{C}\end{array}$ & $\begin{array}{l}\text { Colony count } \mathrm{CFU} \mathrm{g}^{-1} \text { on } \\
\text { TCBS at } 20^{\circ} \mathrm{C}\end{array}$ \\
\hline 01 March 2010 & fresh salmon & 0 & $1.2 \times 10^{5}$ \\
\hline \multirow{2}{*}{05 March 2010} & smoked salmon & 0 & 0 \\
\hline & fresh salmon & 0 & 0 \\
\hline 15 March 2010 & Mussels & 0 & 0 \\
\hline \multirow[t]{2}{*}{22 March 2010} & Mussels & 0 & $2.1 \times 10^{6}$ \\
\hline & Oysters & 0 & $1.2 \times 10^{6}$ \\
\hline \multirow[t]{3}{*}{12 April 2010} & Mussels & $2.8 \times 10^{4}$ & $1.9 \times 10^{6}$ \\
\hline & smoked salmon & 0 & 0 \\
\hline & fresh salmon & 0 & 0 \\
\hline
\end{tabular}


Table 2. Total Enterobacteriaceae numbers in the seafood

\begin{tabular}{lll}
\hline Date of seafood collection & seafood samples & Colony count CFU g ${ }^{-1}$ on EMBA at $37^{\circ} \mathrm{C}$ \\
\hline 01 March 2010 & smoked salmon & 0 \\
& fresh salmon & $2.2 \times 10^{6}$ \\
& Mussels & 0 \\
& smoked salmon & 0 \\
& fresh salmon & 0 \\
15 March 2010 & Mussels & 0 \\
& smoked salmon & 0 \\
22 March 2010 & fresh salmon & 0 \\
& Mussels & 0 \\
12 April 2010 & Oysters & 0 \\
& Mussels & 0 \\
15 April 2010 & smoked salmon & 0 \\
& fresh salmon & 0 \\
& smoked haddock & $2.0 \times 10^{6}$ \\
& fresh haddock & $5.0 \times 10^{2}$ \\
\hline
\end{tabular}

Table 3. Total aerobic heterotrophic counts of the seafood

\begin{tabular}{|c|c|c|c|}
\hline Dates of seafood collection & seafood samples & $\begin{array}{l}\text { Colony count } \mathrm{CFU} \mathrm{g}^{-1} \text { on TSA } \\
\text { at } 30^{\circ} \mathrm{C}\end{array}$ & $\begin{array}{l}\text { Colony count } \mathrm{CFU} \mathrm{g}^{-1} \text { on TSA } \\
\text { at } 20^{\circ} \mathrm{C}\end{array}$ \\
\hline \multirow[t]{2}{*}{01 March 2010} & smoked salmon & 0 & 0 \\
\hline & fresh salmon & $5.8 \times 10^{7}$ & $3.8 \times 10^{7}$ \\
\hline \multirow[t]{3}{*}{05 March 2010} & Mussels & $2.6 \times 10^{5}$ & $6.1 \times 10^{5}$ \\
\hline & smoked salmon & $2.6 \times 10^{5}$ & $1.1 \times 10^{5}$ \\
\hline & fresh salmon & $5.8 \times 10^{5}$ & $3.2 \times 10^{6}$ \\
\hline \multirow[t]{3}{*}{15 March 2010} & Mussels & $3.0 \times 10^{3}$ & $6.5 \times 10^{5}$ \\
\hline & smoked salmon & 0 & 0 \\
\hline & fresh salmon & 0 & 0 \\
\hline \multirow[t]{2}{*}{22 March 2010} & Mussels & $1.1 \times 10^{5}$ & $1.1 \times 10^{7}$ \\
\hline & Oysters & $1.1 \times 10^{5}$ & $1.1 \times 10^{6}$ \\
\hline \multirow[t]{3}{*}{12 April 2010} & Mussels & $9.2 \times 10^{4}$ & $6.2 \times 10^{6}$ \\
\hline & smoked salmon & $1.6 \times 10^{3}$ & 0 \\
\hline & fresh salmon & $1.3 \times 10^{5}$ & $9.7 \times 10^{5}$ \\
\hline \multirow[t]{2}{*}{15 April 2010} & smoked haddock & $1.1 \times 10^{6}$ & $2.1 \times 10^{6}$ \\
\hline & fresh haddock & $1.8 \times 10^{6}$ & $2.0 \times 10^{6}$ \\
\hline
\end{tabular}

Table 4. Total Listeria monocytogenes counts of the seafood samples

\begin{tabular}{|c|c|c|c|}
\hline Date of seafood collection & seafood samples & $\begin{array}{l}\text { Colony count CFU } \mathrm{g}^{-1} \text { on } \\
\text { PALCAM at } 30^{\circ} \mathrm{C}\end{array}$ & $\begin{array}{l}\text { Colony count CFU } \mathrm{g}^{-1} \text { on } \\
\text { PALCAM at } 20^{\circ} \mathrm{C}\end{array}$ \\
\hline 01 March 2010 & fresh salmon & 0 & 0 \\
\hline \multirow{2}{*}{05 March 2010} & smoked salmon & 0 & 0 \\
\hline & fresh salmon & 0 & 0 \\
\hline 15 March 2010 & Mussels & 0 & 0 \\
\hline \multirow[t]{2}{*}{22 March 2010} & Mussels & $1.0 \times 10^{4}$ & $5.0 \times 10^{4}$ \\
\hline & Oysters & 0 & 0 \\
\hline \multirow[t]{3}{*}{12 April 2010} & Mussels & 0 & 0 \\
\hline & smoked salmon & 0 & 0 \\
\hline & fresh salmon & 0 & 0 \\
\hline
\end{tabular}

Typically on PALCAM agar, Listeria colonies demonstrated black haloes with greenish surroundings that were $\leq 1 \mathrm{~mm}$ in diameter; they were round, smooth edged, flat and creamy. Colonies comprised nonsporeforming Gram-positive, tiny rods occurring singly, and in pairs and clusters. Cultures were catalase positive, but oxidase negative. Beta haemolysis was recorded on sheep blood agar. Hydrolysis of aesculin was positive. Acid was produced from xylose, arabitol, ribose, trehalose, M-D- gluconate and M-D-mannose.

The distribution, frequency, number and percentage of bacterial isolates from the seafood:

In Table 5, it may be observed that fresh haddock was the most contaminated species in terms of the diversity of bacteria, followed by fresh salmon and smoked haddock. In total, 19 genera of bacteria were recognised (Table 5). The proportions and prevalence of these taxa have been included in Table 5. 
Bacterial Isolates from Seafood in Scotland

Table 5. Number and percentage of bacterial isolates in the seafood

\begin{tabular}{|c|c|c|c|c|c|c|c|}
\hline \multirow{2}{*}{$\begin{array}{l}\text { Bacterial } \\
\text { Isolate }\end{array}$} & \multirow[t]{2}{*}{ No. $(\%)$} & \multicolumn{5}{|c|}{ Seafood species/ No. (\%) } & \multirow[b]{2}{*}{ Oysters } \\
\hline & & $\begin{array}{l}\text { Fresh } \\
\text { salmon }\end{array}$ & $\begin{array}{l}\text { Smoked } \\
\text { salmon }\end{array}$ & $\begin{array}{l}\text { Fresh } \\
\text { haddock }\end{array}$ & $\begin{array}{l}\text { Smoked } \\
\text { haddock }\end{array}$ & Mussels & \\
\hline Acinetobacter & $2(3.2)$ & $0(0.0)$ & $0(0.0)$ & $1(6.3)$ & $1(7.7)$ & $0(0.0)$ & $0(0.0)$ \\
\hline Aerococcus & $3(4.8)$ & $1(7.7)$ & $0(0.0)$ & $1(6.3)$ & $0(0.0)$ & $1(12.5)$ & $0 .(0.0)$ \\
\hline Aeromonas & $9(14.5)$ & $1(7.7)$ & $1(12.5)$ & $3(18.8)$ & $3(23.1)$ & $1(12.5)$ & $0 .(0.0)$ \\
\hline Bacillus & $1(1.6)$ & $0(0.0)$ & $0(0.0)$ & $1(6.3)$ & $0(0.0)$ & $0(0.0)$ & $0(0.0)$ \\
\hline Brochothrix & $2(3.2)$ & $0(0.0)$ & $0(0.0)$ & $0(0.0)$ & $1(7.7)$ & $0(0.0)$ & $1(25.0)$ \\
\hline Carnobacterium & $3(4.8)$ & $1(7.7)$ & $2(25.0)$ & $0(0.0)$ & $0(0.0)$ & $0(0.0)$ & $0(0.0)$ \\
\hline Corynebacterium & $3(4.8)$ & $2(15.4)$ & $0(0.0)$ & $0(0.0)$ & $0(0.0)$ & $0(0.0)$ & $1(25.0)$ \\
\hline Moraxella & $5(8.1)$ & $0(0.0)$ & $1(12.5)$ & $0(0.0)$ & $3(23.1)$ & $1(12.5)$ & $0(0.0)$ \\
\hline Micrococcus & $1(1.6)$ & $0(0.0)$ & $0(0.0)$ & $0(0.0)$ & $1(7.7)$ & $0(0.0)$ & $0(0.0)$ \\
\hline Pseudomonas & $5(8.1)$ & $1(7.7)$ & $1(12.5)$ & $1(6.3)$ & $0(0.0)$ & $1(12.5)$ & $1(25.0)$ \\
\hline Pseudomonads & $1(1.6)$ & $1(7.7)$ & $0(0.0)$ & $0(0.0)$ & $0(0.0)$ & $0(0.0)$ & $0(0.0)$ \\
\hline Psychrobacter & $1(1.6)$ & $0(0.0)$ & $0(0.0)$ & $0(0.0)$ & $1(7.7)$ & $0(0.0)$ & $0(0.0)$ \\
\hline Shewanella & $7(11.3)$ & $2(15.4)$ & $0(0.0)$ & $4(25.0)$ & $1(7.3)$ & $0(0.0)$ & $0(0.0)$ \\
\hline Staphylococcus & $1(1.6)$ & $0(0.0)$ & $1(12.5)$ & $0(0.0)$ & $0(0.0)$ & $0(0.0)$ & $0(0.0)$ \\
\hline Citrobacter & $2(3.2)$ & $1(7.7)$ & $0(0.0)$ & $0(0.0)$ & $1(7.7)$ & $0(0.0)$ & $0(0.0)$ \\
\hline Enterobacter & $2(3.2)$ & $1(7.7)$ & $0(0.0)$ & $1(6.3)$ & $0(0.0)$ & $0(0.0)$ & $0(0.0)$ \\
\hline Escherichia coli & $6(9.6)$ & $2(15.4)$ & $1(12.5)$ & $2(12.5)$ & $1(7.7)$ & $0(0.0)$ & $0(0.0)$ \\
\hline Serratia & $1(1.6)$ & $0(0.0)$ & $0(0.0)$ & $1(6.3)$ & $0(0.0)$ & $0(0.0)$ & $0(0.0)$ \\
\hline Vibrio & $5(8.1)$ & $0(0.0)$ & $1(12.5)$ & $1(6.3)$ & $0(0.0)$ & $2(25.0)$ & $1(25.0)$ \\
\hline Listeria & $2(3.2)$ & $0(0.0)$ & $0(0.0)$ & $0(0.0)$ & $0(0.0)$ & $2(25.0)$ & $0(0.0)$ \\
\hline Total & $62(100.0)$ & $13(21.0)$ & $8(12.9)$ & $16(25.8)$ & $13(21.0)$ & $8(13.0)$ & $4(6.5)$ \\
\hline
\end{tabular}

All total heterotrophs were isolated using TSA, Enterobacteriaceae representatives were isolated using EMBA, presumptive vibrios were isolated using TCBS and Listeria spp. isolated using PALCAM agar.

\section{Detection of specific spoilage bacteria:}

Table 6 shows the prominent characteristics of fish spoilage bacteria, by their ability to reduce trimethylamine oxide (TMAO) red to trimethylamine (TMA) yellow, to produce $\mathrm{H}_{2} \mathrm{~S}$ when decomposing thiosulphate and or cysteine to form black colonies due to preciptation of FeS. The production of TMA was evidenced by the redox indicator in the medium being changed from red to yellow, and a black precipitate of FeS was formed as $\mathrm{H}_{2} \mathrm{~S}$ was produced from thiosulphate and/or cysteine. The Sh. baltica OS185 and Aeromonas spp. HB-6 were the strongest TMA producers as they were able to reduce TMAO to trimethylamine and to produce $\mathrm{H}_{2} \mathrm{~S}$ within two days of incubation. Other isolates of Sh. baltica, Sh. putrefaciens, A. hydrophila HX 201006-3, A. salmonicida subsp. achromogenes, A. hydrophila strain, C. freundii, E. cloacae were also strong producers of TMA and $\mathrm{H}_{2} \mathrm{~S}$ within three days of incubation. One strain each of Sh. baltica, Sh. putrefaciens, V. metschnikovii, E. coli, pseudomonad and Serratia spp. I-113-31 were late $\mathrm{H}_{2} \mathrm{~S}$ producers (Table 6).

Table 6. Detection of specific spoilage bacteria using trimethylamine oxide medium (TMAO)

\begin{tabular}{|c|c|c|c|}
\hline Bacterial isolate & Bacterial code Red to yellow $\mathrm{H}_{2}$ & & \\
\hline Aeromonas sp. HB-6 & SHB $20{ }^{\circ} \mathrm{C}$ & + & + \\
\hline Aeromonas hydrophila HX201006-3 & SHTA $30{ }^{\circ} \mathrm{C}$ & + & + \\
\hline Aeromonas salmonicida subsp. achromogenes & ZFHTA $30^{\circ} \mathrm{C}$ & + & + \\
\hline Vibrio metschnikovii & FHTI $30^{\circ} \mathrm{C}$ & + & $(+)$ \\
\hline Aeromonas hydrophila & ZFHTA $20^{\circ} \mathrm{C}$ & + & $(+)$ \\
\hline Citrobacter freundii & SHG $37^{\circ} \mathrm{C}$ & + & + \\
\hline Enterobacter cloacae & ZFSG $37^{\circ} \mathrm{C}$ & + & + \\
\hline Escherichia coli & $\mathrm{ZFSH} 37^{\circ} \mathrm{C}$ & + & $(+)$ \\
\hline Pseudomonad & FSB $30^{\circ} \mathrm{C}$ & + & $(+)$ \\
\hline Serratia sp. I-113-31 & ZFHG $37^{\circ} \mathrm{C}$ & + & $(+)$ \\
\hline Shewanella baltica OS678 & ZFHB $20^{\circ} \mathrm{C}$ & + & $(+)$ \\
\hline Shewanella baltica OS185 & FSA $20{ }^{\circ} \mathrm{C}$ & + & + \\
\hline Shewanella baltica & ZFSB $30^{\circ} \mathrm{C}$ & + & $(+)$ \\
\hline Shewanella baltica & FHB $30^{\circ} \mathrm{C}$ & + & + \\
\hline Shewanella putrefaciens & ZFHB $30^{\circ} \mathrm{C}$ & + & + \\
\hline
\end{tabular}

(+) represents late producers of $\mathrm{H}_{2} \mathrm{~S}$

\section{Virulent characteristics of spoilage bacteria:}

Table 7 shows the virulent characteristics of spoilage bacteria, revealing Aeromonas spp. and Shewanella spp. as high producers of lecithinase, lipase, haemolysin, gelatinase and elastinase. The ability of the microorganisms to degrade haemolysin ( $\beta$ - haemolysis) reveals that haemolysin causes a cytolytic effect creating pores in host membranes resulting in cell lysis [20]. Haemolysin is an exotoxin that acts destructively on the blood cell membrane and leads to cell rupture. Haemolysis, which results from the lysis of erythrocyte membranes with release of haemoglobin, consists of $\beta$-haemolysis, i.e. complete degradation, and $\alpha$-haemolysis i.e. the incomplete 
degradation of haemoglobin [21]. Proteases (gelatin) are associated in the growth and spread of the bacterium and contribute to the development of the disease by defeating host host defenses and providing nutrients for the host $[22 ; 23 ; 24]$. Lipases have hydrolytic effect on the lipids of the membrane of the host cells, causes intestinal damage, invasiveness and establishment of infections ([25; 26]. [27] in their study reported that phospholipases associated with fish disease are the lecithinases $\mathrm{C}$ and A1. Furthermore, that phospholipases act as both haemolysin and glycerolphospholipid: cholesterol acyltransferase (glycerolphospholipid: cholesterol acyltransferase, GCAT) is present in all Aeromonas species, and its role in fish virulence may be due to a combination with other factors $[28 ; 29 ; 30]$.

Table 7. Virulent characteristics of spoilage microorganisms

\begin{tabular}{|c|c|c|c|c|c|}
\hline \multicolumn{5}{|l|}{ Spoilage } & \\
\hline Aeromonas sp. HB-6 & + & + & $\mathrm{B}$ & 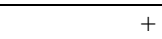 & + \\
\hline Aeromonas hydrophila $\mathrm{HX} 201006-3$ & - & + & $\mathrm{B}$ & - & + \\
\hline Vibrio metschnikovii & - & - & A & - & - \\
\hline Aeromonas hydrophila & + & + & - & - & - \\
\hline Escherichia coli & - & - & - & - & - \\
\hline Pseudomonad & - & - & - & + & + \\
\hline Serratia sp. I-113-31 & + & + & - & - & - \\
\hline \multicolumn{6}{|l|}{ Shewanella baltica OS678 ZFHB $20^{\circ} \mathrm{C}$} \\
\hline & - & - & - & - & - \\
\hline
\end{tabular}

\section{Discussion}

Seafood permits the transmission of many bacterial pathogens [31]. In particular, the microorganisms potentially pathogenic to man, include Salmonella spp., E. coli, St. aureus, L. monocytogenes, Aeromonas spp., $V$. cholerae and V. parahaemolyticus; all of which have been recovered at various times from seafood, namely fresh, frozen and smoked products (fish, shellfish, crustaceans, molluscs) [32;6;33;34]. It is likely that these bacteria may have been contaminants on fish, possibly introduced during harvesting and filleting operations [35; 36; 37]. Moreover, this study revealed the presence of potential pathogenic and spoilage microorganisms, such as Listeria monocytogenes and Aeromonas spp., Vibrio spp., Enterobacteriaceae representatives, Shewanella spp. and pseudomonads. Spoilage microorganisms, including those that produce hydrogen sulphide, for example $S h$. baltica, Sh. putrefaciens and Serratia spp., have been detected from swordfish and tuna alongside non- $\mathrm{H}_{2} \mathrm{~S}$ producers, such as Ps. fluorescens, Ps. fragi and Ac. radioresistens [38].

Various authors have isolated bacterial pathogens from seafood by using a range of conventional methods ([39; 40; 41; 42; 43]. In this study, the homogenates of the seafood were inoculated onto/into general purpose media and selective isolation media for the recovery of specific groups of bacteria, with their identification including the use of 16SrDNA sequencing (www.ncbi.nlm.nih.gov/genbank/).

Among the organisms recovered in this study, a range of Enterobacteriaceae representatives were recovered. The presence of these organisms in fish is regarded as a pointer to possible sewage pollution. Also, some taxa are opportunistic pathogens of fish [44]. It remains a possibility that biogenic amines, such as putrescine, tyramine and histamine, may be produced in fish tissues; the presence of which accounts for some human illnesses [45]. Certainly, the occurrence of $E$. coli may well indicate the possibility of faecal contamination. Notwithstanding, it is argued that measures should be taken to ensure that seafood is not a means of transmission of E. coli namely:

1) to uphold the microbiological quality of the harvesting sites;

2) taking care of post harvest capture;

3) ensuring proper hygiene conditions in the handling processes;

4) with regard to processed food, careful measures should be put in place to avoid recontamination and above all, consumption of raw or undercooked seafood should be avoided [46].

Shewanalla spp. were recovered in this study, but this is not surprising as [47] demonstrated the presence of cells on newly caught fish. It should not be overlooked that the organisms may be opportunistic human pathogens, being associated with bacteraemia and skin and soft tissue infections [48; 49]. However and in agreement with this study, [38] demonstrated Shewanella spp., as a spoilage microorganism by its strong production of TMA and $\mathrm{H}_{2} \mathrm{~S}$. 
The presence of staphylococci on seafood is not unusual. Indeed, [50] reported the isolation of Staphyococus lentus, S. sciuri and S. xylosus from fish and seafood samples (22\% of the total) from Thailand. However, Staphylococcus is not usually regarded as an indigenous component of the microflora of fish, and may well reflect contamination. Yet, the organism may be associated with environments containing high quantities of sodium chloride ([51; 52], such as fish smokers [53]. It is apparent that the detection of staphylococci in fish suggests:

(a) post harvest contamination due to poor hygiene, or

(b) disease in fish [54; 55].

[56] reported that some type of smoked fish may be associated with populations of both L. monocytogenes and $S$. aureus. In this connection, it was noted that $S$. haemolyticus was recovered from smoked salmon in this study.

It is not surprising that vibrios were common in marine fish and shellfish [6; 57]. Certainly, [58] reported that $V$. parahaemolyticus were detected from seafood samples (11.4\% of the total), which were collected from seven fishing companies and local fishermen in Nigeria. In parallel, [59] noted the presence of V. parahaemolyticus in $10.3 \%$ of blue mussels collected from July 2002 to September 2004 at 102 production sites authorized by the Norwegian Food Safety Authorities (NFSA). It was suggested by [60] that the high level $\left(10^{3}-10^{4} \mathrm{~g}^{1}\right)$ of Vibrio spp. in some raw seafood reflected insufficient control in the storage temperatures from the time of harvesting.

Listeria spp., especially L. monocytogenes, were reported in farmed mussels in the North Aegean Sea ([61]. Of relevance, [62] noted that contamination with listeria could occur as a result of improper harvesting, handling, processing and sanitation [63]. It is appreciated that L. monocytogenes is a facultative anaerobic opportunistic intracellular bacterial pathogen, whose primary route of transmission to humans is the consumption of contaminated food [64]. The invasive form of listeriosis is observed primarily in high-risk groups, namely the elderly, individuals with lowered immunity, pregnant women and new borns [65]. The outcome of listeriosis in pregnant women is abortion. In healthy people, it has been reported that L. monocytogenes causes a non-invasive febrile gastroenteritis resulting from the consumption of contaminated smoked trout [66].

\section{Conclusion}

The results from the current study suggest that potential pathogenic and spoilage microorganisms are present in seafood. Seafood safety, which differs according to products, is predisposed to a number of factors such as fish origin, product characteristics, handling and processing practices and preparation before consumption [67]. Adequate cooking of the seafood samples will inactivate the microorganisms, improper handling and cross contamination or raw seafood eating habits, might pose a health hazard, especially to susceptible populations such as the immunosuppressed, pregnant women, children and elderly people especially as regards $L$. monocytogenes[36]. Hazard Analysis and Critical Control Points (HACCP) should be used in all stages of food production and preparation processes including packaging and distribution to identify potential food safety hazards.

\section{Acknowledgements}

This research work was financed by Petroleum Technology Development Fund, Nigeria. The contributions of Prof. Brian Austin and Prof. Alexandra Adams to the work are highly acknowledged.

\section{References}

[1]. Iwamoto, M., Ayers, T., Mahon, B.E. and Swerdlow, D.L, Epidemiology of seafood-associated infections in the United States, Clinical Microbiology Reviews, 23(2), 2010, 399-411.

[2]. Herrera, F.C., Santos, J.A., Otero, A. and Garcı'a-Lo'pez, M.-L., Occurrence of foodborne pathogenic bacteria in retail prepackaged portions of marine fish in Spain, Journal of Applied Microbiology,100, 2006, 527-536.

[3]. Ayers, T., Iwamoto, M., Swerdlow, D.L. and Williams, I. Epidemiology of seafood-associated outbreaks in the United States, 19732006, In Abstract International Association of Food Protection Annual Meeting, Columbus, OH, 2008, 3-70.

[4]. Adeyemo, O.K., Consequences of Pollution and Degradation of Nigerian Aquatic environment on Fisheries Resources, Environmentalist, 23, 2003, 297-306.

[5]. Goja, A.M., Microbiological assessment of three types of fresh fish (Tilapia niloticus, Labeo niloticus and Hydrocynus spp.), New York Science Journal, 6(4), 2013, 49-54.

[6]. Popovic, N.T., Skukan, B.A., Dzidara, P., Coz-Rakovac, R., Strunjak-Perovic, I., Kozacinski, L., Jadan, M. and Brlek-Gorski, D., Microbiological quality of marketed fresh and frozen seafood caught off the Adriatic coast of Croatia, Veterinarni Medicina,55(5), 2010, 233-241.

[7]. Normanno, G., Parisi, A., Addante, N., Quaglia, N.C., Dambrosio, A., Montagna, C. and Chiocco, D., Vibrio parahaemolyticus, Vibrio vulnificus and microorganisms of fecal origin in mussels (Mytilus galloprovincialis) sold in the Puglia region (Italy), International Journal of Food Microbiology, 106, 2006, 219 - 222.

[8]. Ahmad, M., Benjakul, S., Sumpavapol, P. and Nirmal, N.P., Quality changes of sea bass slices wrapped with gelatin film incorporated with lemongrass essential oil, International Journal of Food Microbiology, 155, 2012, 171-178.

[9]. Sallam, K.I., Antimicrobial and antioxidant effects of sodium acetate, sodium lactate, and sodium citrate in refrigerated sliced salmon, Food Control, 18(5), 2007, 566-575.

[10]. McClain, D. and Lee, W.H., Development of USDA-FSIS method for isolation of Listeria monocytogenes from raw meat and poultry, Journal-Association of Official Analytical Chemists, 71(3), 1988, 660-664. 
[11]. Al-Harbi A. H. and Uddin M.N., Bacterial diversity of tilapia (Oreochromis niloticus) cultured in brackish water in Saudi Arabia, Aquaculture, 250, 2005, 566-572.

[12]. Kim, D.-H, Brunt, J. and Austin, B., Microbial diversity of intestinal contents and mucus in rainbow trout (Oncorhynchus mykiss), Journal of Applied Microbiology, 102, 2007, 1654-1664.

[13]. Cowan, S.T. and Constance, S., Outline Classification of Bacterium and Staphylococcus, Microbiology, 3, 1949, 69-73.

[14]. Weisbury, W., Barns, S., Pelletier, D. and Lane, D., 16S ribosomal DNA amplification for phylogenetic study, Journal of Bacteriology, 173(2), 1991, 697-703.

[15]. Jeffries, C.D., Holtman, D.F. and Guse, D.G., Rapid method for determining the activity of microorganisms on nucleic acids, Journal of Bacteriology, 73(4), 1957, 590.

[16]. Gram, L., Trolle, G. and Huss, H.H., Detection of specific spoilage bacteria from fish stored at low $\left(0^{\circ} \mathrm{C}\right)$ and high $\left(20^{\circ} \mathrm{C}\right)$ temperatures, International Journal of Food Microbiology, 4, 1987, 65-72.

[17]. Liu, P.C., Lee, K.K. and Chen, S.N., Pathogenicity of different isolates of Vibrio harveyi in tiger prawn, Penaeus monodon, Letters in Applied Microbiology, 22(6), 1996, 413-416.

[18]. Loghothetis, P.N. and Austin, B., Variations in antigenicity of Aeromonas hydrophila strains in rainbow trout (Oncorhynchus mykiss, Walbaum): an association with surface characteristics, Fish and Shellfish Immunology, 6(1), 1996, 47-55.

[19]. Hasan, J.A.K., Macaluso, P., Carnahan, A.M. and Joseph, S.W., Elastolytic activity among Aeromonas spp. using a modified bilayer plate assay, Diagnostic Microbiology and Infectious Disease, 15(3), 1992, 201-206.

[20]. Ellis, A.E., Burrows, A.S. and Stapleton, K.J., Lack of relationship between virulence of Aeromonas salmonicida and the putative virulence factors, A-layer, extracellular proteases and extracellular haemolysins, Journal of Fish Disease, 11(4), 1988, 309-323.

[21]. Zhang, X.H. and Austin, B., Haemolysins in Vibrio species, Journal of Applied Microbiology, 98, 2005, 1011-1019.

[22]. Sakai, D. K. Significance of extracellular protease for growth of a heterotrophic bacterium, Aeromonas salmonicida, Applied and Environmental Microbiology, 50(4), 1985, 1031-1037.

[23]. Sakai, D. K., Electrostatic mechanism of survival of virulent Aeromonas salmonicida strains in river water, Applied and Environmental Microbiology, 51, 1986, 1343-1349.

[24]. Janda, J.M. and Abbott, S.L., The genus Aeromonas: taxonomy, pathogenicity, and infection, Clinical Microbiology Reviews, 23(1), $2010,35-73$.

[25]. Lee, K.K. and Ellis, A.E., Glycerophospholipid: cholesterol acyltransferase complexed with lipopolysaccharide (LPS) is a major lethal exotoxin and cytolysin of Aeromonas salmonicida: LPS stabilizes and enhances toxicity of the enzyme, Journal of Bacteriology, 172(9), 1990, 5382-5393.

[26]. Timpe, J.M., Holm, M.M., Vanlenberg, S.L., Basrur, V., Lafontaine, E.R., Identification of a Moraxella catarrhalis outer membrane protein exhibiting both adhesion and lipolytic activities, Infection and Immunity,71(8), 2003, 4341-4350.

[27]. Merino, S., Aguilar, A., Nogueras, M.M., Regue, M., Swift, S. and Toma's, J.M., Cloning, sequencing, and role in virulence of two phospholipases (A1 and C) from mesophilic Aeromonas sp. serogroup O: 34, Infection and Immunity, 67(8), 1999, 4008-40013.

[28]. Chacón, M.R., Castro-Escarpulli, G., Soler, L., Guarro, J. and Figueras, M.J., A DNA probe specific for Aeromonas colonies, Diagnostic Microbiology, Infection and Disease, 44, 2002, 221-225.

[29]. Scoaris, D.D.O., Colacite, J., Nakamura, C.V., Nakamura, T.U., Filho, B.A.A., Filho, B.P.D, Virulence and antibiotic susceptibility of Aeromonas spp. isolated from drinking water, Antonie van Leeuwenhoek,93(1-2), 2008, 111-122.

[30]. Figueras, M.J., Beaz-Hidalgo, R., Collado, L. and Martínez- Murcia A.J., Point of view on the recommendations for new bacterial species description and their impact on the genus Aeromonas and Arcobacter, The Bulletin of Bergey's International Society for Microbial Systematics, 2, 2011, 1-16.

[31]. Hosseini, H., Cheraghali, A.M., Yalfani, R. and Razavilar, V., Incidence of Vibrio spp. in shrimp caught of south coast of Iran, Food Control, 15(3), 2004, 187-190.

[32]. Basti, A.A., Misaghi, A., Salehi, T.Z. and Kamkar, A., Bacterial pathogens in fresh, smoked and salted Iranian fish, Food Control, 17, 2006, 183-188.

[33]. Adebayo-Tayo, B.C., Okonko, I.O., Esen, C.U., Odu, N.N., Onoh, C.C. and Igwiloh, N.J.P., Incidence of potentially pathogenic Vibrio spp. in fresh seafood from Itu Creek in Uyo, Akwa Ibom State, Nigeria, World Applied Sciences Journal, 15(7),2011, 985991.

[34]. Joh, S.-J., Ahn, E.-H., Lee, H.-J., Shin, G.-W., Kwon, J.-H. and Park, C.-G., Bacterial pathogens and flora isolated from farm-cultured eels (Anguilla japonica) and their environmental waters in Korean eel farms, Veterinary Microbiology, 163, 2013, $190-195$.

[35]. Huss, H.H, Ababouch, L. and Gram, L., Assessment and management of seafood safety and quality, FAO Fisheries Technical Paper No. 444, Rome: FAO, 2003, 230.

[36]. Papadopoulou, C., Economou, E., Zakas, G., Salamoura, C., Dontorou, C. and Apostolou, J., Microbiological and pathogenic contaminants of seafood in Greece, Journal of Food Quality, 30, 2007, $28-42$.

[37]. Eze, E.I., Echezona, B.C. and Uzodinma, E.C., Isolation and identification of pathogenic bacteria associated with frozen mackerel fish (Scomber scombrus) in a humid tropical environment, African Journal of Agricultural Research, 6(7), $2011,1918-1922$.

[38]. Serio, A., Fusella, G.C., López, C.C., Sacchetti, G. and Paparella, A., A survey on bacteria isolated as hydrogen sulfide-producers from marine fish, Food Control,39, 2014, 111-118.

[39]. Udgata, S.K., Dash, G., Parida, S.K. and Mishra, R., Isolation and identification of human pathogenic Aeromonas hydrophila in seafood of Gopalpur Coast, Orissa, Indian Journal of Animal Research,43(1), 2009, 45-48.

[40]. Eissa, N.M.E., Abou El-Ghiet,E.N., Shaheen, A.A. and Abbass, A. Characterization of Pseudomonas species isolated from Tilapia "Oreochromis niloticus" in Qaroun and Wadi-El-Rayan Lakes, Egypt, Global Veterinaria,5(2), 2010, 116-121.

[41]. Uddin, N. and Al-Harbi, A.H., Bacterial flora of polycultured common carp (Cyprinus carpio) and African catfish (Clarias gariepinus), International Aquatic Research, 4(10), 2012, 1-9.

[42]. Tavakoli, H.R., Soltani, M. and Bahonar, A., Isolation of some human pathogens from fresh and smoked shad (Alosa kessleri) and silver carp (Hypophthalmichthys molitrix), Iranian Journal of Fisheries Sciences, 11(2), 2012, 424-429.

[43]. Oladipo, I.C. and Bankole, S.O., Nutritional and microbial quality of fresh and dried Clarias gariepinus and Oreochromis niloticus, International Journal of Applied Microbiology and Biotechnology Research, 1, 2013, 1-6.

[44]. Rajasekaran, P., Enterobacteriaceae group of organisms in sewage-fed fishes, Advanced Biotechnology, 8, $2008,12-14$.

[45]. Tsai yung-Hsiang, Chang Shiou-chung, Kung Hsien-fung, Wei Chung and Hwang dung-fwu, Histamine production by E. aerogenes in sailfish and milkfish at various storage temperatures, Journal of Food Protection,68(8),2002, 1690-1695.

[46]. Costa, R.A., Escherichia coli in seafood: A brief overview, Advances in Bioscience and Biotechnology, 4, $2013,450-454$.

[47]. Vogel, B.F., Venkateswaran, K., Satomi, M. and Gram, L., Identification of Shewanella baltica as the most important $\mathrm{H}_{2} \mathrm{~S}$-producing species during iced storage of Danish marine fish, Applied and Environmental Microbiology, 71(11), 2005, 6689-6697.

[48]. Chen, Y.S., Liu, Y.C., Yen, M.Y., Wang, J.H., Wann, S.R. and Cheng, D.L., Skin and soft-tissue manifestations of Shewanella putrefaciens infection, Clinical Infectious Diseases, 25(2), 1997, 225-229. 
[49]. Aubert, T., Rovery, C., Bourhaba, K., Singeorzan, S., Heim, M. and Cretel, E., Dermohypodermie bactérienne non nécrosante et bactériémie á Shewanella putrefaciens, La Revuede médecine interne, 30, 2009, 800-802.

[50]. Ananchaipattana, C., Hosotani, Y., Kawasaki, S., Pongsawat, S., Bari, M.D.L., Isobe, S. and Inatsu, Y., Bacterial contamination of retail foods purchased in Thailand, Food Science and Technology Research, 18(5), 2012, 705-712.

[51]. Hansen, L., Gill, T., Truelstrup, T. and Huss, H.H., Effects of salt and storage temperature on chemical, microbiological and sensory changes in cold smoked salmon, Food Research International, 28(2), 1995, 123-130.

[52]. Herrero, M.H., Saques, M., Gerez, H. and Ventura, P., Halotolerant and halophilic bacteria isolated during ripening of salted products, Journal of Food Protection, 61, 2003, 318-323.

[53]. Ferriera, J.G., Hawkins, A.J. and Bricker, S.B., Management of productivity, environmental effects and profitability of shellfish aquaculture, Aquaculture, 264(1-4), 2007, 160-174.

[54]. Huss, H. H., Fresh Fish, Quality and quality changes, FAO Fisheries Series, No. 29. Rome: FAO, $1988,132$.

[55]. Austin, B. and Austin, D.A., Bacterial fish pathogens: In Diseases of farmed and wild fish 4th edn. (Chichester, UK: Springer-Praxis Publishing Ltd. 2007).

[56]. Basti, A.A., Misaghi, A. and Sulehi, T.Z., The study of fungal and bacterial pathogens in salted cols smoked fish in Iran, OIE Seminar on Biotechnology, Bangkok, Thailand, 2003, 9-13.

[57]. Merwad, A.M.A., El-Ghareeb, W.R. and Taisir, S.M., Occurrence of some zoonotic vibrios in shellfish and diarrheic patients with regard to tdh gene in Vibrio parahaemolyticus, Journal of American Science, 7(9),2011, 449-459.

[58]. Adeleye, I.A., Daniels, F.V. and Enyinnia, V.A., Characterization and pathogenicity of Vibrio spp. contaminating seafoods in Lagos, Nigeria, Internet Journal of Food Safety, 12, 2010, 1-9.

[59]. Bauer, A., Østensvik, Ø., Florvåg, M., Ørmen, Ø.andRørvik, L.M., Occurrence of Vibrio parahaemolyticus, V. cholerae, and V. vulnificus in Norwegian Blue Mussels (Mytilus edulis), Applied and Environmental Microbiology, 72(4), $2006,3058-3061$.

[60]. Aberoumand, A.U., Occurrence and characterization of potentially pathogenic Vibrio species in Seafood Products and Mariculture Systems. World Journal of Fish and Marine Sciences, 2 (5), 2010, 376-382.

[61]. Soultos, N., Iossifidou, E., Ambrahim, A., Psomas, E., Tzavaras, I., Koutsopoulos, D. and Lazou, T., Listeria monocytogenes in mussels (Mytilus galloprovincialis) harvested from North Aegean coastal area, Turkish Journal of Veterinary and Animal Sciences, 38, 2014,50-53.

[62]. Vernocchi, P., Vei, M.M., Lanciotti, R., Suzzi, G. and Gardini, F., Characterization of Mediterranean mussels (Mytilus galloprovincialis) harvested in Adriatic Sea (Italy), Food Control, 18(12), 2007, 1575-1583.

[63]. Bremer, P.J., Fletcher, G.C. and Osborne, C., L. monocytogenes in seafood, New Zealand Institute for Crop and Food Research Limited, Auckland, New Zealand, 2003.

[64]. Vazquez-Boland, J.A., Kuhn, M., Berche, P., Chakraborty, T., Dominguez-Bernal, G., Goebel, W., Gonzalez-Zorn, B., Wehland, J. and Kreft, J., Listeria pathogenesis and molecular virulence determinants, Clinical Microbiological Review, 14(3), $2001,584$.

[65]. Gelbíčová, T. and Karpíšková, R., Occurrence and Characteristics of Listeria monocytogenes in ready-to-eat food from retail market in the Czech Republic, Czech Journal of Food Science, 27(2), 2009, S2-3-S2-7.

[66]. Miettinen, M.K., Siitonen, A., Heiskanen, P., Haajanen, H., Bjorkroth, K.J. and Korkeala, H.J., Molecular epidemiology of an outbreak of febrile gastroenteritis caused by Listeria monocytogenes in cold-smoked rainbow trout, Journal of Clinical Microbiology, 37(7), 1999, 2358-2360.

[67]. Huss, H.H., Reilly, A. and Ben Embarek, P.K., Prevention and control of hazards in seafood, Food Control, 11(2), 2000, $149-156$. 